\title{
THE USE OF SEED PROTEIN BANDING PATTERNS FOR IDENTIFICATION OF PASTURE CULTIVARS
}

Grasslands Division, P/ant Physiology Division, DSIR, Palmerston North

Abstract

Because of the growing number of pasture cultivars used in NZ and the difficulty of reliably separating cultivars of the same species by morphological characters, seed protein banding patterns have become a useful supplementary means of cultivar identification for the purposes of seed certification and plant useful supplementary means of cultivar identification for the purposes of seed certification and plant
variety rights applications.

Sodium dodecylsulphate polyacrylamide gel electrophoresis of proteins extracted from ground seed samples produces distinctive patterns of bands representing seed storage proteins of different molecular weights. The procedure can be carried out in two days using viable or dead seed, and the results are not affected by site and season of growth. Although individual seeds of outbreeding species such as perennial ryegrass and white clover produce different banding patterns, the combined population representing the cultivar remains constant unless there has been genetic shift during seed multiplication.

Species for which this procedure is being successfully used include the ryegrasses and fescues, browntop, cocksfoot. bromes, red and white clovers, subterranean clover, serradella and lotus. Even cultivars as closely related es Nui and Ellen ryegrasses and Huia and Pitau white clovers can be separated by careful work. Because of minor technical differences between runs, all cultivars to be compared must be run on the same gel.

Keywords: Seed certification, Plant variety rights, sodium dodecylsulphate polyacrylamide gel electrophoresis.

\section{INTRODUCTION}

Pasture cultivars are notoriously difficult to identify in the field because they are inherently variable and generally separated by only small morphological differences, and because their characteristics are greatly affected by the environment (climate, soil, season) in which they are growing. Furthermore, as they are nearly all cross-pollinated they are susceptible to pollen contamination from nearby crops of the same species, while legumes (especially white clover) can also be contaminated by buried seed..

Consequently any accessory method of identification that is independent of external conditions and can act as a check on seed purity is a valuable tool for seed certification authorities, especially as the number of different cultivars grown or multiplied in New Zealand has greatly increased. It can also supplement morphological descriptions for the purpose of characterising cultivars for plant variety rights. Determination of seed protein banding patterns by sodium dodecylsulphate polyacrylamide gel electrophoresis (SDS-PAGE) was shown to be very successful for these purposes (Gardiner et al. 1986), and its applications in New Zealand wil be further described.

\section{METHODS}

Seed of all lines tested was obtained from the NZ Forage Germplasm Centre, Grasslands Division, DSIR, Palmerston North.

\section{Sample Preparation}

Proteins were extracted from ground seed meals using one of two methods. The first, which was used for cocksfoots, involved extraction of alcohol-soluble proteins and their subsequent acetylation (Doll and Andersen 1981; Gardiner and Forde 1987 in press) prior to analysis. For all other species in the study total seed proteins were extracted from seed meats (20 mg for grasses except Agrostis $15 \mathrm{mg}, 10 \mathrm{mg}$ for legumes) using $0.25 \mathrm{ml}$ of the extraction medium of Smith and Payne (1984). 


\section{Electrophoresis}

The basic procedure for the analysis of the extracted seed proteins by SDS-PAGE is described in Gardiner et a/. (1986). The concentration of acrylamide used in making the gels (and hence and pore size within the gel) varied according to the species concerned: ryegrass and fescue $11 \%$, legumes, cocksfoot and bromes, 12.5\%. browntop 15\%. The gels were 1 $\mathrm{mm}$ thick with $5 \mathrm{~mm}$ wide slots, and the volumes of extracts used in the analysis were as follows: cocksfoot $7.5 \mu \mathrm{l}$, white clover $5 \mu \mathrm{l}$, grasses other than cocksfoot $4 \mu \mathrm{l}$, red clover and serradella $3 \mu$ l, lotus $2 \mu l$ and subterranean clover $1.5 \mu$ l. Concentrations of buffers in the gels and the upper electrode reservoir were $\times 1.5$ higher than quoted in Gardiner ef al. (1986). To provide good cooling, water at $4 \pm 1^{\circ} \mathrm{C}$ was circulated through the central core of the electrophoresis apparatus (Biorad Protean II). In addition, the lower buffer was extended as far as possible up the gel and the whole apparatus stood in an ice/water bath on a magnetic stirrer which stirred the lower buffer reservoir. This system allowed a relatively short run time ( $1 \mathrm{~h}$ at $16 \mathrm{~mA}$ gel then approximately $4 \mathrm{~h}$ at 10 watts/gel) until the tracking dye reached the end of the gel.

\section{RESULTS}

Previous work (Gardiner et al. 1986; Gardiner \& Forde 1987 in press) has already established that although individual genotypes (seeds) of an outbreeding cultivar vary in their seed protein banding patterns, the combined pattern of the population is very stable, and also that banding patterns of different harvests of the same cultivar from different years and sites are normally very constant, though poor quality seed may give a weak pattern. Consequently the patterns of different cultivars of variable species such as perennial ryegrass (Lolium perenne L.) can safely be compared on the basis of single samples. The seed does not need to be viable, so recent lines may be checked against original isolations or collections. Cultivars of predominantly inbreeding species such as pink serradella (Ornithopus sativus L.) and prairie grass (Bromus willdenowii Kunth) show much greater uniformity in the banding patterns of different individual seeds.

As there are often unavoidable small differences between running conditions for different gels, all cultivars and species to be compared should be run on the same gel. Different gel strengths are required to give optimal separation of the proteins of interest for the different groups because the seed proteins vary in their molecular weight range, and also because only a proportion of these protein bands exhibit variation between cultivars (Gardiner eta/. 1986, Gardiner \& Forde, manuscript in prep.).

Some species and genera produce many more variable protein bands useful for identification purposes than others, for example red clovers (Trifolium pratense L.) are easier to separate by seed protein banding patterns than are white clovers ( $T$. repens $L$.), and fescues (Festuca) than cocksfoots (Dactylis glomerata L.), but no species tested has proved to be invariable in this respect. Limitations of space preclude presenting the branding patterns of all cultivars and species which have been analysed, but examples illustrating variation between cultivars of the major pasture and turf species in New Zealand are given in Figs 1 and 2, and points of interest will be discussed. Fuller presentation of variation in individual grass species can be found in papers cited above, and for legumes in Gardiner $\&$ Forde (in prep.).

\section{Ryegrasses (Lolium spp.)}

The increased number of ryegrass cultivars commercially available in New Zealand has created a real need for supplementary methods for their identification. SDS-PAGE of seed proteins separates all the cultivars and regional ecotypes of perennial ryegrass (Fig. 1), even Grasslands Nui and Ellett, which are derived from the same local population in Mangere but have become slightly differentiated during the breeding of Nui. The additional band which is diagnostic of Nui is indicated. (Presence or absence of Lolium endophyte does not affect the 


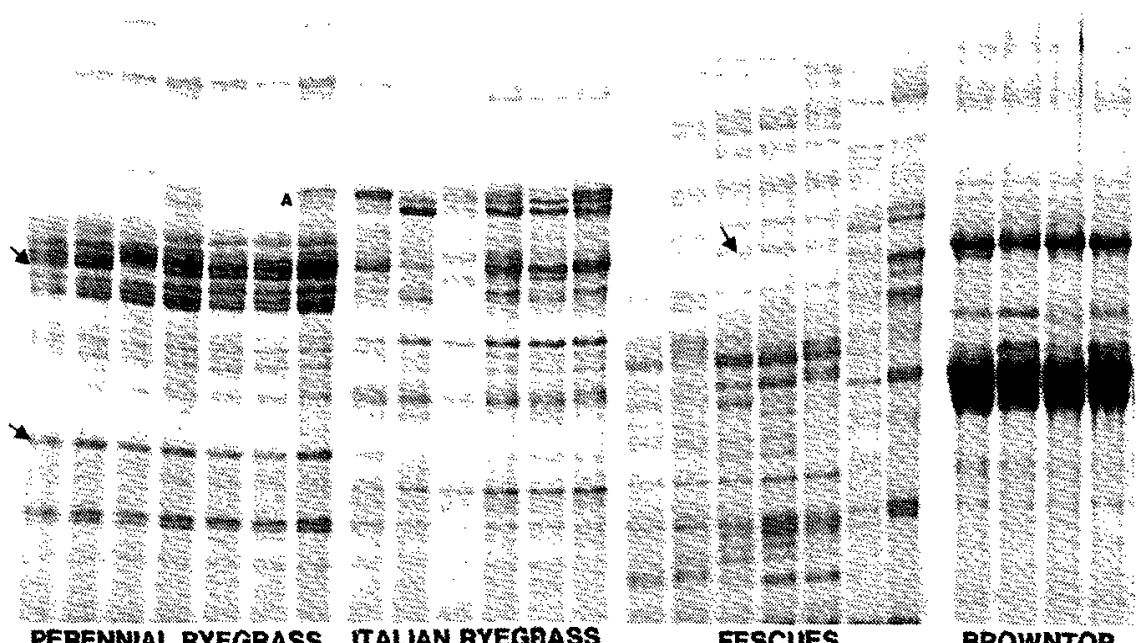

\section{PERENMIAL RYEGRASS TALIAN RYEC}

FESCUES

BROWNTOP

Figure 1: Seed protein banding patterns of different cultivars of ryegrass, fescue and browntop following SDS. polyacrylamide gel electrophoresis. The acrylamide concentration in the get used in analysing the ryegrass and fescue proteins was $11 \%$ and for the browntops, $15 \%$. Cultivars shown are as follows: Perennial Ryegrass - Ell, Ellett; Yat, Yatsyn

I; Dro, Droughmaster; Per, Persistor; Rua, Ruanui; Ari, Ariki; Italian Ryegrass - Man, Manawa; Tam, Tama; Par, Paroa:

Con, Concord; Lam, Lemtal; Pro, Progrow; Chewings Fescue- NZC, NZ Chewings; Coo. Cook; Creeping red fescueTas, Tasman; Daw, Dawson; Son. Sonnet: Tall Fescue _ NZT, NZ wild type: Roa; Browntop - NZ, NZ commercial; Sef. Sefton; Egm. Egmont; Dry, Grasslands dryland browntop selection. Arrows indicate bands of interest mentioned in the text.

WA, Kar apa "AK MAT HAM TUM PAW KOP MUI PIT TAM

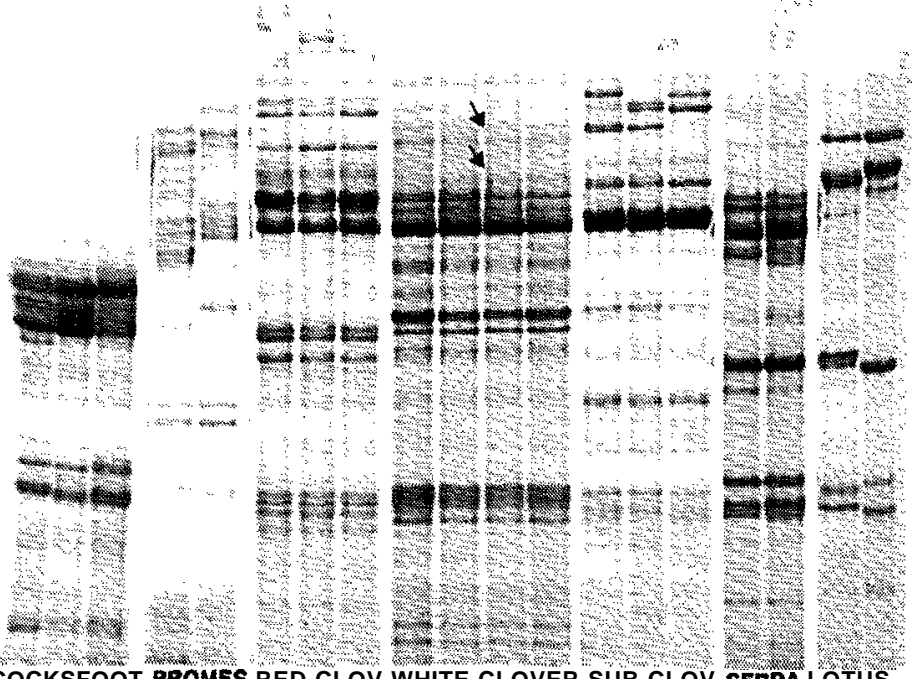

COCKSFOOT BROMES RED CLOV WHITE CLOVER SUB CLOV SERRA LOTUS

Figure 2: Sanding patterns following SDS-polyacrylamide gel electrophoresis of proteins extracted from seeds of different cultivars of pasture grasses and Igumes. The acrylamide concentration in the gel was $12.5 \%$. Cultivars shown are as follows: Cockstoot - Wan, Wana; Kar. Kara; Apa, Apanui; Bromes - Hak. Hakari; Mat, Matua; Red Clover - Ham. Hemua Tur, Ture Paw, Pawera: White Clover- Kop Kopu. Hui, Huia: Pit, Pitau: Tah, Tahora; Subterranean Clover MB, MI Barker; Tai, Tallarook; Woo. Woogenellup; Serradella - Koh, Koha; Mai, Maia; Lotus $\leadsto$ Mak, Maku; Cor, $L$. comiculatus. The banding differences distinguishing Huia and Pitau are indicated with arrows. 
banding pattern). Yatsyn I, also derived from Mangere material, is more clearly distinguishable from Ellett. Similarly, Droughtmaster and Takapau Persistor, which both derive from the Takapau district, can easily be separated by their seed protein bandjng patterns. The hybrid ryegrass Grasslands Ariki shows strong similarity with perennial ryegrasses in its banding patterns (as in its agronomic characteristics) -e.g. band indicated by lower arrow. However, unlike most cultivars of that species it has prominent bands in the $A$ region like Italian ryegrass.

Italian ryegrasses (L. multiflorum Lam.) (see also Forde et al. this Proceedings) show a clear species difference in banding pattern from perennial ryegrass, as well as individual minor differences which distinguish all the cultivars and regional ecotypes known in New Zealand. Some more persistent cultivars (including the hybrid ryegrass Grasslands Manawa) have the perennial band (lower arrow indicated on Fig. 1) characteristic of L. perenne, presumably as a result of hybridism and introgression with this species (Gardiner et a/. 1986).

\section{Fescues (Festuca spp.)}

Seed proteins of fescues have very variable banding patterns which provide a large number of bands useful for distinguishing species and cultivars (Fig. 1). Grasslands Roa tall fescue can be readily distinguished from NZ wild type (and also many overseas cultivars), and Grasslands Cook from NZ Chewings fescue (F.rubra L.), Grasslands Tasman creeping red fescue and other cultivars of this type such as Dawson and Sonnet have a seed protein band in common (indicated in Fig. 1) which distinguishes them from the Chewings Fescue.

\section{Browntops (Agrostis spp.)}

Although it is difficult to obtain clear banding patterns, the turf browntop cultivars Grasslands Sefton and Grasslands Egmont (A. capillaris L.) show differences in protein banding in the central portion of the gel and are also distinguishable from NZ commercial browntop (Fig. 1). Dryland browntop (A. castellana Boiss \& Reut.) also has a different seed protein banding pattern, but exhibits no species-diagnostic bands which separate it from the closely related $A$. capillaris.

\section{Cocksfoots (Dactylis glomerata L.)}

It is more difficult to obtain good preparations of cocksfoot seed proteins than of ryegrass and fescues, and only a small number of bands show variation. Nevertheless the three New Zealand cultivars Grasslands Apanui, Grasslands Kara and Grasslands Wana can be clearly distinguished from each other (Fig. 2) and from overseas cultivars (Gardiner \& Forde 1987 in press).

\section{Bromes (Bromus spp.)}

These predominantly inbreeding species produce clear seed protein banding patterns with a number of variable bands (Fig. 2). Prairie grass (6. willdenowii Kunth), a South American hexaploid species, and Alaska brome (6. sitchensis Trin.), a North American octoploid species, have quite different characteristic banding patterns, as exemplified in Fig.2 by Grasslands Matua and Grasslands Hakari. Matua can also be separated from other cultivars of B. willdenowii (Gardiner \& Forde, 1987 in press).

\section{Red clover (Trifolium pratense L.)}

Red clover cultivars are readily separated because the seeds produce an abundance of clear protein bands (Gardiner \& Forde, in prep.). The three New Zealand cultivars, Grasslands Hamua, Grasslands Turoa and Grasslands Pawera, can be clearly differentiated by their banding patterns in the upper third of the gel (Fig. 2).

\section{White clover (T. repens L.)}

It is especially vital to be able to identify white clover cultivars and check seed harvests for purity because of the problem of buried seed contamination, and the morphological overlap between the cultivars. 
Distinguishing white clover by seed protein banding patterns is not as easy as for red and subterranean clover, as there are few variable bands and these are mostly faint and close together in the upper third of the gel. However, careful work eventually enabled characterisation of all four New Zealand cultivars, even Grasslands Huia and Grasslands Pitau which are very closely related genetically. The bands which distinguish Pitau from Huia are indicated on Fig. 2. Grasslands Tahora and Grasslands Kopu are more readily distinguished.

\section{Subterranean clover (T. subterraneum L.)}

This inbreeding species produces extremely clear seed protein banding patterns which serve to differentiate a large number of cultivars (Gardiner \& Forde in prep.). Patterns for the three cultivars sown in New Zealand (Mount Barker, Tallarook and Woogenellup) are demonstrated in Fig. 2.

\section{Serradella (Ornithopus spp.)}

Grasslands Koha pink serradella is the first cultivar of $\boldsymbol{P}$. sativus released in New Zealand and one of only a handful in the world. It is possible to separate all available varieties by their seed proteins except two from Poland (Vinar and. Biata) which are both white-flowered and appear identical when grown. Fig. 2 shows the pattern for Koha in comparison with Maia, a Portuguese cultivar. Seeds of the other cultivated species, yellow serradella (0. compressus) and slender serradella (0. pinnatus), have quite distinct banding patterns (Gardiner \& Forde in prep.).

\section{Lotus spp.}

Grasslands Maku lotus (L. pedunculatus Cav.) and birdsfoot trefoil (L. corniculatus L.) are becoming increasingly important in New Zealand agriculture. As would be expected, the two species can be clearly differentiated by their seed protein banding patterns, as shown in Fig. 2 where Maku is compared with birdsfoot trefoil.

\section{DISCUSSION}

Analysis of seed protein patterns after SDS-PAGE provides a relatively rapidlyperformed adjunct to the more traditional methods of assessment of cultivar identity. Its value to the New Zealand herbage seed trade is already being demonstrated. It is currently being used by the Seed Testing Station of the Ministry of Agriculture and Fisheries as a check on their procedures for ryegrass seed certification, and seed protein banding patterns are now routinely submitted by Grasslands Division DSIR in support of applications for Plant Variety Rights for new cultivars of the genera mentioned above. In addition, the technique is proving useful for the identification of lines and cultivars and the tracing of breeding lineages by plant breeders at Grasslands Division.

Seed protein banding patterns are also of use for taxonomic studies in some genera and have many potential uses in seed bank management (Forde \& Gardiner 1986). Species may be identified without growing out seed samples, duplications among accessions identified, and checks made that seed multiplication has not resulted in genetic change.

\section{References}

Doll H., Andersen B. 1981. Preparation of barley storage protein, hordein, for analytical sodium dodecylsulphate polyacrylamide gel electrophoresis. Analytical Biochemistry 1 75: 61-66.

Forde M.B., Gardiner S.E. 1966. Seed protein gel electrophoresis in genetic resource management. Plant Breeding Symposium DSIR 1986. Agronomy Society of NZ Special Publication No. 5. 21-26.

Gardiner S.E., Forde M.B., Slack C.R. 1986. Grass cultivar identification by sodium dodecylsulphate polyacrylamide gel electrophoresis. NZ Journal of Agricultural Research 29: 193-206.

Gardiner S.E. Forde M.B., 1967. SDS polyacrylamide gel electrophoresis of grass seed protens: A method for cultivar identification Of pasture grasses. Seed Science \& Technology: 15 (2) (in press).

Smith D.B., Payne P.I. 1964. A procedure for the routine determination of electrophoretic band patterns of barley and malt endosperm proteins. Journal of the National institute of Agricultural Botany 16: 487-498. 